\title{
Gostar da música: percurso de uma paixão
}

$\frac{\text { Ana CRIStina Fricke MatTE }}{\text { Universidade de São Paulo/USP }}$ 


\section{Resumo}

As relações passionais do ouvinte com a música aparecem em todos os dizeres sobre música, desde aqueles produzidos pelo público quanto aqueles produzidos pelos próprios artistas. Esses dizeres são capazes de revelar o estilo do gostar de música e definir os estilos musicais conforme esse gostar, ao invés de classificá-los conforme elementos de análise musical strito sensu. No caso da música popular, uma análise como essa possibilita explicar como elementos musicais tão semelhantes - mesmas escalas, mesma harmonia - são usados em diferentes estilos de canção produzindo efeitos de sentido completamente diferentes. Também explica como um mesmo assunto na letra da canção produz aceitabilidade em um estilo musical e rejeição em outro, mostrando a identidade entre o estilo do gostar de música e o próprio estilo do sujeito. $\mathrm{O}$ foco deste trabalho é a música como objeto de valor.

\section{Palavras-chave}

música, paixão, estilo, MPB

\section{Abstract}

The passional relationship of the listener and the music appear in every telling about music, since those produced by the public until those produced by musicians. These speeches are capable of to reveal the style of liking music and to define the musical styles predicted from it, instead of classifying them based in elements from the musical analysis. For the popular music, such analysis can explain how musical elements so similar - same scales, same harmony - are used in different styles of songs producing completely different effects of sense. It can explain too how a common matter in the lyric of the song produce acceptability in one musical style and, in another one, produce rejection, showing the identity between the style of liking music and the style of the subject itself. The focus of this work is the music as a valued object.

\section{Key words}

music, passion, style, popular Brazilian music 


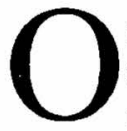

gosto por um determinado estilo de música é, aparentemente, uma operação simples: identificamo-nos com determinado estilo em função do entorno cultural e musical que nos acompanha durante a existência. No entanto, classe social (/poder/), presença/ausência de acesso à cultura elitizada (/saber/), faixa etária (/querer/) e até religião (/dever/). são alguns dos elementos que podem figurar na constituição desse gosto. Trata-se, portanto, de uma modalização bastante complexa e especifica, que pode mudar durante o percurso do sujeito por motivos que parecem não ter nada a ver, diretamente, com a música, mas, sim, com os valores nela investidos.

No entanto, se alguém reclama do "barulho" que a vizinha chama de música, o que é que esse alguém está questionando? Se mudassem somente os valores investidos, caberia a incidência de tal questionamento sobre a condição de objeto? Ora, facilmente percebemos que há uma diferença explícita entre o que um e outro ator do nosso exemplo banal chama de música. Uma diferença no plano da expressão e também no plano do conteúdo, pois trata-se de um objeto bastante peculiar, tal como outras formas de arte, um objeto-linguagem. No caso desse sujeito hipotético, podemos afirmar num primeiro momento que não lhe interessa o que diz a "nãomúsica" que a vizinha ouve, nem a especificidade daquela "nãomúsica" que ela ouve naquele determinado momento, mas o como essa música fala, pois parece-lhe impossível alguém dizer algo com tal linguagem "primitiva" ou "grosseira" ou "caótica" ou seja lá o que for. No entanto, os dois "adoram" música. O que é música, afinal? 


\section{Expressão de emoções}

Dizer que a música expressa emoções é outro lugar comum que tomaremos como ponto de partida.

No estudo da avareza, Greimas e Fontanille dão às emoções o claro sentido de expressão corpórea das paixões, representando um momento específico do percurso passional:

O efeito de 'irrupção' do somático na superficie do discurso, que caracteriza de modo geral a emoção, decorre da reembreagem sobre o sujeito tensivo que postulamos para justificar a instalação do simulacro passional no discurso: convocando, na cadeia discursiva, as modulações do sentir e do devir, a reembreagem prepara a irrupção somática da emoção; é exatamente nesse momento preciso do percurso passional que o sujeito-que-sente lembra que tem um corpo. (Greimas \& Fontanille, 1993, p.154-155, sublinhado nosso)

Admitindo que a emoção expressa pelá música é a lembrança do corpo do sujeito-que-sente no processo gerativo do efeito de paixão, estaremos admitindo que a música é vivenciada como um momento do percurso passional de cada ator-ouvinte.

Juntemos a isso o fato de que a música cristaliza um tempo, nos valores intensos pela organização em torno de motivos melódicos e rítmicos e nos valores extensos por propiciar a vivência repetida de um momento passional:

(...) valores "intensos" (definidos por funções contraidas no contato imediato de elementos) e valores "extensos" (definidos por funçôes a distância e regulados pela extensão global da peça), conceitos hjelmslevianos transportados ao domínio estético por Claude Zilberberg. (Tatit, 1994, p.13)

Compor, por exemplo, é criar uma duração que mereça ser preservada e destacada do ciclo rotativo das comunicações 
cotidianas. Pressupõe, portanto, uma parada do fluxo utilitário para dar origem a um novo movimento, cuja direção valoriza cada vez mais a própria duração ou, se preferirmos, o próprio espaço de duração da obra. (Tatit, 1994, p. 260)

Assim, ouvimos música para reviver somaticamente estados passionais que não necessariamente correspondem ao momento do percurso do sujeito-que-sente, ou seja, o que a música propicia são simulacros somáticos de estados passionais que vivemos retrospectiva ou prospectivamente. A noção de simulacro, para a semiótica, é indispensável para a compreensão de todo e qualquer relacionamento intra e inter sujeitos, incluindo-se aí os sujeitos da enunciação (as figuras do produtor e do receptor pressupostas pelo texto).

Mas, dirá a vizinha, o vizinho não entende a música que ela gosta porque não viveu tal estado nem o desejou. Engano da vizinha: o vizinho, exceto em algum caso patológico, viveu, vive ou deseja ainda viver os estados passionais dos quais a música fala. Portanto, como dissemos anteriormente, a identidade do vizinho com determinada música, bem como a identidade da vizinha, não dependem exclusivamente do conteúdo passional da determinada música.

Se vemos a música como um objeto descritivo investido por um valor específico, ou seja, um estado passional, ouvir música significa entrar em conjunção com esse valor. Mas a música ou "nãomúsica" da vizinha pode até falar de um estado passional semelhante àquele das canções ouvidas e amadas pelo vizinho. Mudou o objeto descritivo e não mudou o valor investido? Nesse caso, é o objeto descritivo o que o vizinho rejeita ao dizer " isso não é música"? Ou é o valor do valor investido que a expressão musical modifica num nível profundo da produção do sentido?

É nessa direção que se encaminha o presente trabalho. A música, como expressão de emoções, traria à tona com sua materialidade elementos do percurso gerativo das paixões que são culturalmente determinados. Dessa forma, ela expressa, além da emoção, o valor da emoção em dado contexto cultural; se a emoção fosse o objeto-valor que a música como elemento do nível da expressão 
semiotiza, a moralização da emoção seria a valência desse objeto valor e justamente o palco da polêmica.

Mas a música como expressão de emoções acarreta também outras significações. Dissemos que a emoção é a expressão corpórea das paixões (Greimas \& Fontanille 1993, p.154-155). Nesse caso, a música pode ser vista como uma materialização que simula o corpo-que-sente. Sua materialidade sonora não pode ser vista nem tocada: não tem a cômoda possibilidade de distância que o visível propicia nem a possibilidade igualmente cômoda do toque voluntário, como diria Herman Parret ${ }^{1}$. O prazer de ouvir é o prazer de ser tocado e visto por uma música que não é visível nem tateável.

Porém, o prazer e a dor de ouvir estão intimamente ligados: a mesma presença invisível e a mesma involuntariedade no toque que propiciam prazer se nos trazem algo desejado, propiciam dor se nos trazem algo indesejado ${ }^{2}$. E tanto maior a dor quanto mais forte a corporalidade da emoção indesejada.

É importante aqui não confundir o prazer de ouvir com o prazer como conteúdo semiótico da canção: estamos agora falando da música como expressão e não como conteúdo; no caso do conteúdo, por exemplo, um dos motivos da música da vizinha ser indesejável para o vizinho poderia ser falar de prazer num amor platônico, o qual para o vizinho teria conotações de dor sublime, portanto excluindo a noção de prazer.

Além disso, devemos levar em consideração que a música é uma linguagem semi-simbólica, pois seus elementos não constituem signos, suas unidades do plano da expressão e do plano do conteúdo não são conformes, como na linguagem verbal, mas se podem levantar categorias no plano da expressão e categorias no plano do conteúdo que se inter-relacionam no processo semiótico; o estudo dessa correlação já está bastante avançado nos trabalhos de Luiz Tatit (1994 e 1996).

Em suma, a materialidade da música é importante por ser capaz de mudar a valência dos objetos-valor que ela oferece ao

1 Considerações baseadas em palestra proferida pelo professor Herman Parret em 30/10/1998 na FFLCH - USP, Departamento de Lingüistica.

2 Idem. 
enunciatário (o ouvinte pressuposto). E se, como acabamós de concluir, a música é a materialização de um simulacro de corpo-quesente, o corpo é elemento central na constituição dessa valência; ou seja, na constituição do valor dos valores investidos nos objetos emotivos que cada música oferece: Se o ouvinte chegar a depreender o gesto entoativo da fala no "fundo". da melodia produzida pela voz, terá uma compreensão muito maior daquilo que sente quando ouve um canto. (Tatit 1997, p.102, grifo nosso).

É importante reter, dessa rápida abordagem da música como expressão de emoções, principalmente dois pontos:

- a música é expressão de estados passionais;

- a expressão desses estados se faz através da simulação de um corpo-que-sente.

Em suma, a música é um simulacro de emoção.

\section{Objeto de circulação}

O estudo da música como objeto pássional num sistema de produção de valores foi discutido por nós em Matte (1999), motivo pelo qual optamos por somente relatar no presente tópico os principais pontos da argumentação proposta. Um dos elementos de "discórdia" em relação aos tipos de música que circulam em nossa sociedade diz respeito à natureża do sistema de circülação no qual a música se insere. Fazer música para vender é uma postura abominada em alguns meios, mesmo se a sobrevivência dessa música depende de sua venda. A música então ganha ares míticos dé objeto que está acima de sua própria materialidade e isso, como veremos nos exemplos do tópico final, atinge a própria imagem do artista que a produz.

O objeto música é um objeto com as seguintes características:

- pode serpartilhado;

- não pode ser retido nem acumulado,

- não existe forà do têmpo.

Por isso, o advento do disco mudou a história da música. Antes dele, a ánica forma de usufruir a música era sua execução ao vivo. Agora, a presença do intérprete é virtualizada, no disco, no rádio ou na TV. Antes, o objeto música só poderia ser vendido em pequena 
escala, diretamente pago ao executante (no teatro, no bar, no restaurante, na rua). Agora, qualquer um pode vender música, e a música é ouvida anonimamente nos lugares mais curiosos - e menos identificados com esse tipo de audição - tais como um supermercado.

No sistema financeiro, vender muito é sinal de que o produto é bom, otimizando a relação custo e qualidade; porém, quando se trata de produtos culturais, nem todos concordam com isso. O tipo de música que está vendendo muito é visto como de menor qualidade pela parcela de público que não se identifica com ele. Nesse meio, a preposição "para" é pejorativa, pois qualifica a música com uma utilidade que vai contra a lei mítica do "estar acima de sua materialidade". Música para dançar, música para enfeitar novela, música para brincar, música para namorar, música para esperar dentista,

\section{Música para tocar no ambiente \\ Música para escovar os dentes \\ Música para tocar na parada \\ Música pra dar risada \\ (Arnaldo Antunes)}

Seja lá qual for a sua utilização, no que concerne à visão do meio onde a música "útil" é desvalorizada, a música não pode ser "para" e, se é, não vale muita coisa, não merece muita atenção.

Pode-se assim dizer que o meio mítico-musical estaria sendo regido por um regime de exclusão, enquanto o meio da música para vender seria regido por um regime de participação:

$O$ regime de exclusão tem por operador a triagem e, se o processo atinge seu termo, leva à confrontação contensiva do exclusivo e do excluido e, para as culturas e as semióticas que são dirigidas por esse regime, à confrontação do "puro" e do "impuro". (Fontanille \& Zilberberg, 2001, p.29)

No caso, trata-se da música mítico-musical. Freqüentemente observamos, nos dizeres mais comuns da comunidade de ouvintes com ela identificados, a correlação subjacente entre a qualidade como 
elemento intenso e a quantidade - de público - como elemento extenso, por exemplo. Quanto maior o público, menor a qualidade (fig. 1).

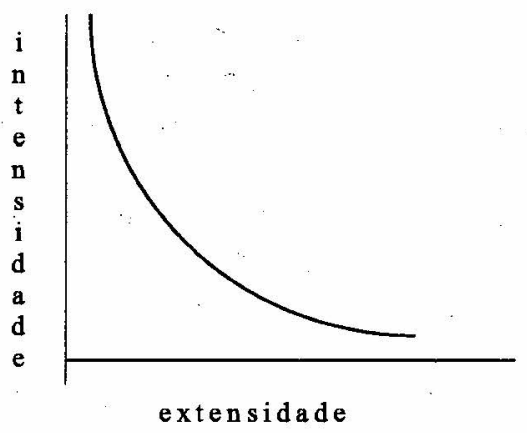

Figura 1: (Fontanille \& Zilberberg 2001, p.26)

$O$ regime de participação tem por operador a mistura $e$ produz a confrontação distensiva do igual e do desigual: no caso da igualdade, as grandezas são intercambiáveis, enquanto no da desigualdade, as grandezas se opõem como "superior" $e$ "inferior".(Fontanille \& Zilberberg, 2001, p.29)

Assim, a lógica da música para vender é exatamente oposta, tratando-se de um regime de participação: quanto maior o público, superior a música, maior a qualidade (fig. 2)

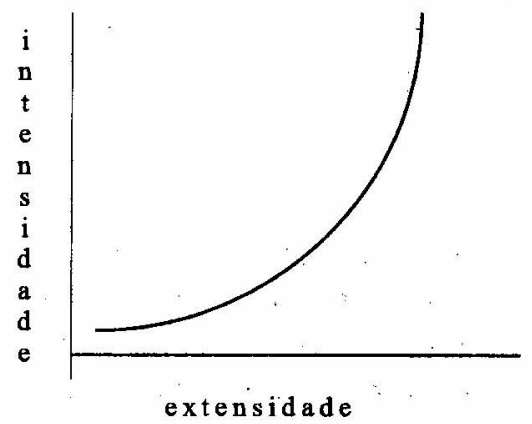

Figura 2 (Fontanille \& Zilberberg 2001, p.26) 
Assim, é possível afirmar que a música para se opõe à música de - do autor, do intérprete -, o processo de mistura motivando a lógica do grande público e das massas enquanto um processo de triagem justifica a lógica de uma "minoria inteligente".

O que dizer então de uma música "para vender"? Ela perde toda a possibilidade de existência no mundo mítico-musical, já que este a exclui (lógica da triagem)? Resolver esse paradoxo é impossível e se o artista "do coração" de amantes daquela música mítica faz sucesso e ganha dinheiro, geralmente o fato é tomado apenas como uma decorrência natural; ele está desculpado, pois não fez a música "para vender", ele fez música pela música e não tem culpa se tanta gente assim, de repente, resolveu querer ouvi-la. A pontinha de ironia não é inocente, mas não pressupõe qualquer valorização positiva ou negativa de tal ou qual música, fique claro.

No entanto, a música da maioria ganha espaço, financiamento, motivos, desculpas, ganha ares de cultura nacional - veja o caso da lambada - e, com isso, de certa forma ofende a música (as músicas) da minoria. Uma questão de poder, num mundo industrializado e capitalista no qual o que vale é a quantidade. Eis um dos momentos em que gostar de música ganha contornos passionais: no confronto entre maioria e minoria (e minorias e minorias), um espaço onde:

- o objeto não-consumível torna-se consumível, pois uma musicalidade ameaça extingüir a outra,

- o objeto não-acumulável torna-se acumulável, pois uma musicalidade ganha dimensões enormes em comparação com a outra,

- o objeto partilhável torna-se não-partilhável, pois uma musicalidade não é compreendida pela outra,

- o objeto que não pode ser retido é retido, pois a musicalidade minoritária permanece restrita a pequenos grupos e não mais circula.

Diante desse quadro, freqüentemente os músicos dizem que se trata de um problema de maior ou menor complexidade musical, que uma música complexa não pode ser compreendida por uma maioria inculta. Outra vez teremos aqueles que valorizam positivamente essa complexidade, enquanto outros a desvalorizam. 
Dizer "inculto" já é uma forma de valorização. O que é que está em jogo?. Um defende a escala maior e o outro uma escala mixolídia com quarta aumentada?

O objeto música é feito, sim, de escalas e ritmos, e harmonias, e a complexidade de seu uso remete a diferentes musicalidades, também. Mas Por trás dos recursos técnicos tem que haver um gesto (...) (Tatit 1996, p.14).

\section{Paixão individual vs. paixão coletiva}

A música como simulacro de emoções e a música como objeto num sistema de circulação de valores são abordagens que remetem a diferentes momentos do percurso gerativo das paixões. A primeira diz respeito ao momento da sensibilização e a segunda refere-se ao momento da moralização, conceitos aqui utilizados conforme propostos por Greimas e Fontanille no Semiótica das Paixões (1993, p.140-156) e que podem ser assim resumidos:

A sensibilização é a criação do simulacro passional do sujeito. A convocação de um estilo semiótico, ou seja, dispositivos modais dinamizados e selecionados pelo uso caracterizam uma disposição do sujeito para um determinado fazer patêmico. A patemização dessa disposição, momento intenso da sensibilização, é a transformação tímica do sujeito discursivo em sujeito que sente, sofre, reage, se emociona; é a emoção que assinala o cumprimento dessa junção tímica, ao mesmo tempo em que dá a palavra ao próprio corpo. Portanto, o que a emoção expressa é a faceta reflexiva da paixão, a auto-elaboração da competência do sujeito, em direção a uma imagemfim. Em outras palavras, a sensibilização é individual, e só será culturalmente determinada quando sofrer o processo de moralização, pois uma mesma configuração modal e aspectual terá diferentes conotações em diferentes culturas.

- Já a moralização é o acionamento de uma avaliação externa sobre o comportamento observável do sujeito sensibilizado. Entra em cena um observador social, coletivo, que avalia o conjunto modal e aspectual expresso pela emoção do sujeito individual classificandoo, conforme uma escala de medidas preestabelecida coletivamente, 
como aceitável ("na medida") ou como excessivo (ou insuficiente). Estamos trabalhando aqui a noção de insuficiente como "excesso de falta", pois a oposição fundamental em termos de paixões é a dupla excesso/medida; tal leitura possibilita compreender que o insuficiente seja tão passional quanto o excessivo, somente sendo aceitável aquilo que se encontra "entre" essas duas posições, ou seja, uma justa medida.

A paixão é, além de reflexiva, intersubjetiva, pois só existe na medida de um confronto entre o percurso existencial do sujeito e os limiares e limites sócio-culturais. Sendo assim, a moralização é social.

Por ocasião da convocação em discurso, se a configuração se organiza exclusivamente do ponto de vista do sujeito apaixonado, apenas a sensibilização se manifesta; e se a configuração se organiza do ponto de vista de um observador social, a moralização surge, pressupondo e ao mesmo tempo mascarando a sensibilização. (Greimas \& Fontanille, 1993, p.150)

Essas duas dimensões do percurso passional - a dimensão individual, ou sensibilização, e a dimensão social, ou moralização auxiliam a compreensão da música tal como a estamos estudando. Numa dimensão individual, ela propicia ao sujeito-enunciatário viver retrospectiva ou prospectivamente um simulacro passional, pois ela é um simulacro de emoção e, como tal, a expressão simulada de uma disposição patemizada de um sujeito diante de um objeto. Numa dimensão social, ela é a avaliação da sensibilização do sujeito; apesar de simulada, o sujeito que adere ao dispositivo passional proposto pela música, ou seja, gosta dela, o faz porque concorda com a aspectualização proposta por ela para tal efeito patêmico.

Se num determinado meio social tal conjunto corresponde à graduação esperada para aquele determinado efeito (por exemplo, o amor platônico), a moralização será positiva e a paixão pela música não será posta em xeque. Caso contrário, como o vizinho ao avaliar a música da vizinha como excessiva, a moralização será negativa e questionará não o efeito passional em si, mas a maneira como ele é compreendido por tal simulacro emotivo. 
Outra vez chegamos a esse ponto: não é o valor investido no objeto descritivo música que é questionado (um valor particularmente investido em determinado objeto), mas o valor desse valor, ou seja, sua valência, determinada pelo comportamento observável, que nesse caso é a expressão musical - um valor difuso, de fundo social, que de certa forma situa o objeto no âmbito da coletividade. Mas em sendo o comportamento observável a questão central da paixão por música, por que os elementos musicais são insuficientes para determinar os estilos?

\section{Escalas musicais ou escalas aspectuais?}

Assim como a linguagem verbal, a música possui também sua sintaxe e sua semântica. Compor, arranjar, escrever canções, criar uma interpretação são todos movimentos que necessariamente passam por organizações teórico-musicais mais ou menos explícitas, conforme o estilo ou tipo de música que se está fazendo. Assim como a sintaxe da língua, a sintaxe musical é descritiva, procura organizar as ocorrências de determinadas combinações já usadas e é arbitrária, geralmente, no que concerne a explicações do "por que funciona assim?". Os elementos musicais, tais como são descritos pelos estudos de harmonia, composição, arranjo, rítmica, orquestração, regência, canto, tanto na área popular quanto na erudita, podem ser utilizados para efeitos muito dessemelhantes, conforme o contexto. E esse contexto sempre acaba sendo explicado de maneira vaga. Afinal, o objetivo desses estudos não é explicar, mas descrever, não é o conteúdo, mas a expressão. Por isso uma mesma escala maior ou o mesmo ritmo de valsa podem ser alegres, ritualísticos, infantis ou fúnebres, dependendo de como e em que situação forem utilizados.

Estaríamos remetendo o sentido da música ao contexto externo, ou ao mundo natural, ou a referentes sociais? Esta é a solução encontrada por aqueles que pensam na sintaxe e na semântica musicais como os únicos patamares de apreensão do sentido musical. Outros diriam que o sentido da música "escapa à razão" e desistem de explicar qualquer coisa. 
A semiótica da canção é uma proposta específica para a análise do conteúdo da música. Não cabe aqui entrar em detalhes sobre seus mecanismos nem discuti-los em profundidade; é suficiente notar que esșa teoria levanta elementos básicos para a compreensão da linha de discussão que adotamos. Em linhas gerais e demasiadamente sucintas, a semiótica da canção propõe o estudo da geração do sentido na canção como um redimensionamento do sentido do texto verbal na interface fala/canto por meio de uma aspectualização e de uma tensivização propostas por melodia e ritmo, çomo, numa breve e segura introdução ao assunto, nos ensina Tatit (1997:87-116).

A melodia é compreendida como repetição/inovação, extenso/intenso, gradual/saltado; ritmo é regular/irregular, extenso/intenso, acelerado/desacelerado. Todas essas categorias de expressão encontram correspondência com categorias do conteúdo (euforia/ disforia, conjunção/disjunção e categorias aspectuais diversas).

Um olhar mais atento e menos apressado do que este que podemos ter aqui vai nos levar a perceber que a música é uma linguagem que ressalta o caráter contínuo do sentido, seus componentes do nível profundo, enquanto a linguagem verbal ressalta o caráter descontínuo e o discreto.

Isso corrobora a imagem da música em duas dimensões, a individual, sensibilizante, lembrança do corpo num simulacro de emoção, e a social, moralizante, que coloca o sensível numa escala graduada e marcada por limites e limiares claros.

Podemos perceber nesse momento que o "ser da música" também existe em duas dimensões. Existe numa dimènsão técnica, a da sintax́e e da semântica musicais, que permite afirmar que a música do vizinho e a música da vizinha são apenas manifestaçõès diferentes de uma mesma linguagem; existe também numa dimensão semiótica, em que valores culturais relativos a paixões são investidos em cada objeto-música e valorizados diferenteménte pelo cóntorno que o próprio objêto lhes confere.

Os estilos musicais são determinados em ambas as dimensões. Rock pauleira, samba-canção, lambada, xote, o estilo é definidopelo uso de determinadas escalas, harmonias, ritmos e andamentos, no que diz respeito à dimensão que denominei técnica, mas é 
também e, simultaneamente, definido por densidades, intensidades, acelerações e descontinuidades que, em planos diferentes, evocam um grau de tensão correspondente a uma disposição patemizada e culturalmente determinada, no que diz respeito à dimensão semiótica.

Sendo assim, quem define os contornos do conteúdo passional da canção é essa dimensão semiótica, cujo conteúdo de sensibilização individual é expresso simuladamente por um corpoque-sente. Dito de outra forma, são escalas aspectuais e não escalas musicais os fatores de engendramento de sentido na música, por mais que ela se sirva destas para evidenciar aquelas, e não poderia ser de outra maneira. Além disso, somente a inserção da música num sistema de circulação de valores que transformam suas características objetais é capaz de caracterizar o gostar de música como uma paixão, vestindo a sensibilização com o olhar quantitativo da moralização.

\section{Objeto e anti-objeto: boa música, música boa}

Simulacro de emoção, a música é também simulacro de corpo, corpo invisível, corpo intocável, mas corpo presente. O corpo também é evocado pela música de diferentes maneiras; conforme 0 estilo, ele é denso, forte, vasto, condensado, virtualizado, realizado, próximo, distante, erótico, platônico etc. A imagem do artista que defende cada estilo, ou seja, cada tipo de música, é uma imagem corporificada conforme esse simulacro de corpo que o estilo define. Para ser cantora não é necessariamente preciso cantar: basta corresponder à corporalidade do tipo de música que se apresenta; foi o caso de Carla Perez. Mas uma cantora que defenda um tipo intimista e requintado de música precisa cantar, pois seu corpo deve esvanecerse, desaparecer diante da música mítica e sobre-humana. A cantora que não canta só será menos cantora do que a que canta caso seja avaliada por um observador pertencente a um quadro sócio-cultural que privilegie o tipo mítico de música: É importante frisar que essa terminologia "mítico", intimista etc., é apenas uma aproximação cujo único objetivo é facilitar a exemplificação, não fazendo qualquer alusão valorativa a um ou outro estilo musical. O observador mitico 
moralizará o não-cantar como insuficientemente musical e excessivamente corporal.

No outro extremo, outro observador social diante da cantora "acorpórea" e vocalmente rebuscada vai moralizar seu cantar como insuficientemente significativo e excessivamente técnico, por exemplo. Dizer quem está correto depende de qual ponto de vista pretendemos defender; depende do quadro cultural ao qual cada um de nós pertence e por isso jamais haverá uma palavra final sobre o assunto.

Tomemos alguns poucos exemplos: dois trechos de entrevistas com músicas publicadas pelo Pasquim (O som do Pasquim, 1976) e um trecho de texto publicado no songbook de Edu Lobo, organizado por Almir Chediak (1994). Os trechos foram escolhidos com uma certa dose de arbitrariedade, pois havia em cada uma das entrevistas e reportagens dezenas de exemplos de diferentes aspectos da paixão pela música. As análises que seguem, atendo-se a esses recortes mínimos dos textos, visam a introduzir o sistema da paixão por música sem demorar-se em detalhes que, por mais ricos que sejam, desviam o olhar do analista para outras paragens; por isso a abordagem procura rastrear apenas os principais indícios do estudo recém apresentado.

\section{Qualidade vs. presença - análise do trecho 1}

trecho 1

Chico - Dá inclusive pra compor. Dá pra tocar. Mas em gravação minha não ouso tocar violão. Nunca toquei violão em gravação minha. A não ser na primeira, "Pedro Pedreiro". Toco mal, por deficiência motora. Faço nada direito com as mãos.

Ziraldo - Música você também nunca estudou?

Chico - Mais tarde tomei aula com a Dona Graça. Aprendi alguma coisa de teoria. Depois, com o contato com o violão, sei o que estou fazendo. Sei fazer cifra. (Entrevista com Chico Buarque de Holanda no Chopinho \& Comidinhas, dia 28 de novembro 3/4 1975; O som do Pasquim, 1976, p.14) 
Nessa entrevista vemos um Chico Buarque que não sabe tocar, sabe pouquíssima teoria musical, mas sabe fazer músicas. Ao mostrar-se inepto para tocar violão e displicente em relação ao rigor que o estudo musical requer, Chico de maneira alguma se desvaloriza: ele cria uma oposição entre corpo e mente, na qual a música se insere valorizando, euforizando a mente.

O exercício mental da música, no entanto, é valorizado enquanto dom, não enquanto esforço. O esforço, mesmo que seja para estudar música, é "trabalho braçal", é disforizado nesse contexto. $O$ compositor faz claramente a distinção entre a dimensão técnica da música, à qual dá pouca importância, pois é apenas descritiva (sei o que estou fazendo), e a dimensão semiótica da música (dá inclusive pra compor).

O compositor é, então, hierarquicamente sobreposto ao intérprete: ele não toca em suas gravações, ele usa o violão para compor mas não sabe tocar. E não sabe tocar porque não faz nada direito com as mãos. A mão simboliza o corpo: não saber usar as mãos não desqualifica o compositor, porque no quadro cultural no qual ele se insere o corpo tem a difícil função de desaparecer por trás do simulacro de emoção, da lembrança de corpo-que-sente; nesse regime de triagem, do mundo míticomusical, o corpo deve ser só lembrança: quanto menor a presença, maior a qualidade.

Podemos esboçar o estilo do sujeito relativo a esse tipo de gostar de música na correlação entre a profundidade extensa da presença física - em que incluímos a técnica interpretativa, o conhecimento musical e a teatralidade do cantor - e a profundidade intensa da qualidade musical, resultando numa correlação inversa que identifica Chico Buarque com o mínimo de presença e o máximo de qualidade (fig.3).

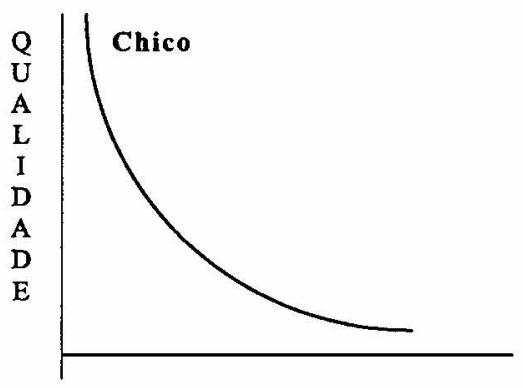

PRESEN CCA

Figura 3 


\section{Eficiência vs. quantídade de público: análise do trecho 2}

trecho 2

Luiz Lobo - Por falar em gênero, quem criou o seu gênero?

Waldick - Eu. Aliás, eu não, eu venho de uma transa muito grande, entende? Ninguém criou gênero nenhum.(..) Nós vivemos copiando as coisas; o Roberto Carlos também vem daquele estilo americano de rock e coisa e tal, agora ele está apelando, querendo ser um Waldick Soriano, cantando dor de cotovelo. Porque o que vende mesmo é dor de cotovelo. O cara que for cantar essas besteiras ai morre de fome, e o Roberto Carlos não é trouxa não, viu?(...). (Waldick Soriano: a vida é uma constância de conseqüências de vários gêneros, entende? - edição n.155, 20/6 a 26/6/72; O Som do Pasquim, 1976, p.36-37)

Waldick - Hoje é só ter o cabelinho comprido, usar uma calcinha apertada, não sei como, e tatatal. E já gravá. Mas naquele tempo era fogo, né?

Jaguar - O que você cantou pra impressionar o cara?

Waldick - Eu cantei: "Hoje que a noite éstá calma/ e que minha alma esperava por ti/ aparecesté afinal (...) (...) (Waldick Soriano: a vidà é uma constâñcia de conseqüências de vários gênẹros, entende? - edição n.155; 20/6 a 26/6/72; O Som do Pasquim 1976, p.43)

Waldick - Para mim o público que tem gostado mais da boa música é o público do Norte e Nordeste do Brasil; inclusive o povo que mais pode comprar discos. Porque só compra long-play, não compra compacto, viu? Só tem gente pobre aqui no Sul, entendè? Então sabe o que acontece; se eu vendo discos há muito tempo, "então eu sou bom mesmo. (Waldick Soriano: a vida é uma constância de consequiências de vários gêneros, entende? - edição n.155, 20/6 a 26/6/72; O Som do Pasquim, 1976, p.46) 
Dois aspectos são fundamentais na configuração do estilo semiótico-passional de Waldick Soriano: em primeiro lugar, uma valorização do corpo enquanto voz, oposto ao corpo enquanto imagem; em segundo lugar, a valorização positiva da eficiência contraposta à criatividade.

1) O primeiro aspecto acontece na dimensão individual, no plano da sensibilização passional. O cantor valoriza um saber cantar que não dispensa mas transcende o corpo, estende o corpo para um além-sẹr. Em termos de conteúdo passional, a dimensão individual, ou sensibilizaçã̃o, nesse trecho só fica clara numa leitura mais atenta: ao desprestigiar o cabelinho comprido e a calcinha apertada, ele está euforizando uma imagem masculina marcada pelo excesso de força, de tamanho, de peso, de espaço.. Esşa imagem surge em toda sua plenitude em outros trechos da entrevista em que ele fala sobre mulher, não reproduzidos aqui. A voz masculina, segundo esse modelo, não deve misturar-se ao corpo: é na sua invisibilidade e involuntariedade tátil que ela atinge a mulher de maneira inefável, deixando-a sem defesas (lembrando Herman Parret: o ouvido não tem defesas...).

Sendo assim, é preciso saber cantar (interpretar), ou seja, valoriza o lado pragmático, um saber-fazer que a música de Chico Buarque coloca num nível inferior. Não vem ao caso se os instrumentistas de Chico são bons ou fracos, ou se Waldick canta bem mesmo, o que importa para a configuração da paixã̃o por música são os efeitos de sentido buscados pelos integrantes dos diferentes estilos que eles procuram representar aqui, nas suas falas. Chico também gosta da figura do malandro, mas não é o mesmo malandro que Waldick Soriano.

2) O segundo aspecto diz respeito à dimensão social, ao plano da moralização passional. Não importa o que fazemos, importa se o que fazemos vende ou não. Portanto, Waldick se insere no quadro social em que a preposição "para" é eufórica; música para vender é boa música. Note-se que ele não fala diretamente nem da dimensão técnica da música nem da dimensão semiótica. $O$ saber que ele valoriza é completamente passionalizado (e pragmático, pois tem em vista o lucro), moralizado, ele faz a boa música, não essas besteiras. 
Assim, o estilo semiótico do sujeito que gosta da música de Waldick Soriano, do ponto de vista do próprio músico, correlaciona a profundidade extensa do público - quanto mais vende, melhor - com a profundidade intensa da eficiência, que traduz a acepção proposta por Waldick para a palavra

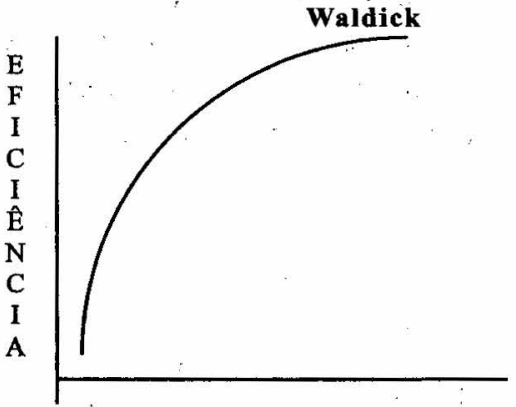

QUANTIDADE

Figura 4 "melhor", portanto correspondendo ao sentido de "boa música" nesse quadro de valores. Cabe notar que, como a quantidade - valor extenso - é muito valorizada, a curva ascendente deve necessariamente ser abaulada para cima, indicando que a eficiência - valor intenso pode ser limitada, mas não o é a quantidade (fig. 4).

\section{Outra curva: análise do trecho 3}

trecho 3

Há uma curiosidade nisso: o sucesso não era propriamente dele, era de suas canções. Até onde me lembro, Edu nunca foi um compositor que cantasse para grandes públicos. Preferia ambientes menores, espetáculos em pequenas casas noturnas que esgotavam sua lotação semanas a fio. $\mathrm{Na}$ voz de outros intérpretes $3 / 4$ principalmente Elis Regina 3/4 suas canções vendiam dezenas de milhares de cópias e eram apresentadas para públicos gigantescos. Na voz de seu autor tudo ficava restrito a ambientes menores. Porque também nesse aspecto ele não mudou nada ao longo dos tempos: continua detalhista ao extremo, continua de uma exigência sem fim, quando se trata de seu próprio trabalho. (Notas para um perfil Eric Nepomuceno; Chediak, 1994, p.10) 
No texto de Eric Nepomuceno sobre Edu Lobo novamente temos representadas as duas dimensões da paixão por música: a sensibilização e a moralização.

$\mathrm{Na}$ dimensão individual, do simulacro passional, o trecho escolhido é bastante completo: o artista e sua musicalidade são definidos em função de uma medida em que o corpo deve permanecer virtualizado; sua voz é pequena (restrita a ambientes menores), pois sua música é grande (o sucesso não era propriamente dele, era de suas canções).

O corpo fica tão diluído que o próprio ato de cantar passa a segundo plano, numa hierarquia poderosa que institui a canção (a composição) como o cimo, o cume, o ápice. O pequeno da voz (e das apresentações públicas) permite à canção mostrar-se como resultado de um trabalho detalhista e exigente.

Sutilmente, esse trecho remete a outro, do mesmo livro, em que as qualidades técnicas do compositor são valorizadas, tais como sua capacidade de ler partitura e seu gosto pela música erudita (boa música?). A dimensão técnica da música não aparece separada da dimensão semiótica; a expressão é valorizada porque a música não tem corpo, não tem voz, só tem forma. Trata-se, sem dúvida, de outro estilo semiótico da paixão pela música, de outra disposição patemizada a qual valoriza sobremaneira a emoção (ou o simulacro de emoção) que a torna observável.

Já na dimensão social, a justa medida está nessa negação do corpo, nessa negação do sujeito. Outros intérpretes (donos de vozes, dotados de corpo) podem até vender sua música para milhares de ouvintes, usar essa música mítica, divinizada pelo texto de Nepomuceno, para integrar-se ao sistema de circulação de valores em que a música é negociável; mas, segundo esse texto sua música não foi feita para ser vendida, ela mantém-se acima disso, o compositor mantém-se sutil, quase ausente. A imagem do autor permanece na justa medida em que a música é só som.

Seu anti-objeto, defendido por Waldick Soriano, apesar de não ser manifestado, fica no limiar do texto, na voz de Elis Regina e seu imenso público, uma cantora corporal que arrebata multidões, mas que o faz com uma música inocente, pois não foi feita para 
vender, e por issó é "'desculpada". O anti-objeto é, portanto, rejeitado discursivamente por meio de sua exclusão'enunciativa, mas surge no horizonte cultural da moralização negativa de uma música-produto, música "para".

O público de Edu Lobo e o público de Chico Buarque se interseccionam, podendo-se lembrar, inclusive, que os dois autores têm diversas canções em parceria. Mas foi possível perceber uma diferença entre o estilo do sujeito descrito por Chico para o Pasquim e do sujeito descrito por Nepomuceno ao falar de Edu. Ambos valorizam a mínima presença como máxima qualidade, $\circ$ que nos garante uma correlação inversa entre a profundidade intensa da qualidade e a profundidade extensa da presençá física. No entanto, segundo os textos analisados, a lógica da triagem em Chico Buarque é mais exclusiva que aquela de Edu Lobo, ou seja: bastâ afastar-se úm pouco do mínimo de presença que a qualidade cai, enquanto em Edu Lobo um limite próximo da máxima inten'sidade é mantido enquanto aumentase a presença, desde a visibilidade conferida à técnica musical até a permissão aos arroubos corporais e comerciais de seus intérpretes. Desta forma, não podemos opor o estilo de um ao estilo do outro, mas podemos apontar

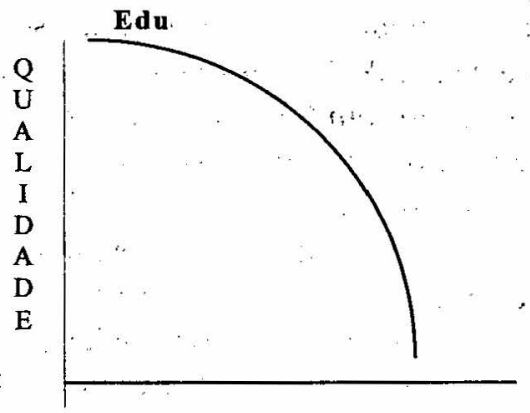

PRESENÇA

Figura 5

diferenças, que vão ser representadas como no gráfico abaixo, como uma outra forma da correlação inversa entre a presença - extensa e a qualidade - intensa - (fig. 5).

\section{A música vale por sua semiose}

A paixão por música, em suma, não é um estudo particular de caso, mas uma proposta de organização do fenômeno da paixão 
pela música na nossa sociedade. A paixão, em cujo palco atores de uma mesma sociedade defendem quadros de valores culturais com diferentes moralizações dos dispositivos modais e aspectuais, é um efeito de sentido construído na linguagem. Levantamos para a análise da música na sociedade a dimensão técnica e a dimensão semiótica, bem como inserimos a música num quadro passional completo. A música, assim, configurou-se como simulacro de emoção, emoção tanto no sentido coloquial quanto no sentido semiótico (lembrança do corpo-que-sente, manifestação da sensibilização passional). Essa abordagem possibilita analisar a moralização das diferentes sensibilizações expressas em diferentes estilos musicais. Esse trabalho aponta para a análise da tensividade da paixão, um elemento profundo cuja característica geral permitirá agrupar diferentes universos passionais e culturais, tais como a música.

Inicialmente falamos em identidade, depois falamos em "questão de poder"; tudo depende do lado que estamos defendendo. Não é possível falar em música na nossa sociedade sem tomar partido por tal ou qual estilo semiótico e, por mais que tenhamos tentado, é bastante provável que essas análises tenham acabado por privilegiar um ou outro estilo e, quem sabe, até mesmo, por excesso de precaução, aquele com o qual não nos identificamos.

Trocando em miúdos, o consumo de música seria caracterizado pela oposição não de idéias, mas de estilos. A boa música não seria uma única música, não diria respeito a um único estilo musical; a música será boa ou não, e até será música ou não, conforme seu estilo semiótico seja condizente ou não com o estilo semiótico privilegiado pelo grupo social com o qual se identifica o avalista.

Da mesma maneira, a boa música não pode ser pré-moldada: não há fórmulas musicais que produzam sempre boas músicas, pois não se trata de avaliar escalas de notas nem seqüências rítmicas, mas escalas de valores e ritmos pessoais e sociais. Assim, a música vale por sua semiose: por aquilo que significa, mas também, e principalmente, pela maneira como o diz. 


\section{Bibliografia}

CHEDIAK, A. 1994. Songbook Edu Lobo. Rio de Janeiro: Lumiar Editora.

COLEÇÃO EDIÇÕES DO PASQUIM. 1976. O som do Pasquim. Entrevistas com os astros da música popular brasileira, v. 6 . Rio de Janeiro: CODECRI.

FONTANILLE, J. \& ZILBERBERG, C. 2001. Tensão e significação/ trad. Ivã Carlos Lopes, Luiz Tatit e Waldir Beividas. São Paulo: Discurso Editorial: Humanitas/FFLCH/USP.

GREIMAS, A. J. \& FONTANILLE, J. 1993. Semiótica das paixões - dos estados de coisas aos estados de alma./trad. Maria José Rodrigues Coracini. Série Temas \# 33. São Paulo: Ática.

MATTE, A. C. F. 1999. "Música: objeto passional num sistema de circulação de valores" In: Caderno de discussão do CPS, eds. Ana C. M. A. de Oliveira, Luís E. Costa, Yvana F. de Brito. São Paulo: Centro de Pesquisas Sociossemióticas. p. 77-83.

TATIT, L. 1994. Semiótica da canção - melodia e letra. São Paulo: Escuta.

1996. O cancionista - composição de canções no Brasil. São Paulo: EDUSP.

. 1997. Musicando a semiótica - ensaios. São Paulo: Annablume. 